\title{
Postoperative Pain in Endodontics
}

\author{
Olcay Özdemir* \\ Zonguldak Bülent Ecevit University, Faculty of Dentistry, Department of Pedodontics, Turkey
}

*Corresponding author: Olcay Özdemir, Zonguldak Bülent Ecevit University, Faculty of Dentistry, Department of Pedodontics, Zonguldak, Turkey.

Received Date: September 21, 2020

Published Date: October 01, 2020

\begin{abstract}
This review aims to evaluate the definition, reason, and management of postoperative pain during and/or after endodontics treatment. Postoperative pain is very common and its prevalence ranges between $3 \%$ and $58 \%$ of all endodontic patients and they usually evaluate postoperative pain as a skill criterion of the clinician. Postoperative pain is multifactorial and observed as a result of acute periapical inflammation in response to chemical, mechanical, and/or microbial damage of the periapical area during the endodontic treatment. Therefore, patients should always be informed that pain may be experienced after the procedure and clinicians should follow up-recent studies about the factors that may cause pain, and if possible, adapt clinical procedures accordingly.
\end{abstract}

Keywords: Endodontics; Management of postoperative pain; Postoperative pain; Root canal preparation

Abbreviations: PP: Postoperative pain; VAS: Visual Analogue Scale; WBS: Wong-Baker Faces Pain Rating Scale; FPS: Faces Pain Scale; VDS: Verbal Descriptor Scale; NRS: Numeric Rating Scale; NSAIDs: Nonsteroidal anti-inflammatory drugs

\section{Introduction}

Pain is one of the main reasons for dental anxiety. During and/ or after the endodontic treatment some patients experience pain. This situation is called postoperative pain (PP). According to the literature, PP is very common and its prevalence ranges between $3 \%$ and $58 \%$ of all endodontic patients [1]. Besides, it was reported that more than $50 \%$ of patients who experienced any discomfort after treatment stated that the condition was severe [2]. The presence and control of PP are very important for the treatment comfort and confidence of the patient. Preoperative pulpal status, presence of pain before treatment, or irritation of the periapical area during the procedure may result with PP [3-6]. Patients who will undergo endodontic treatment should be informed before treatment that there may be some of PP to avoid an unexpected situation. This study aimed to review the definition, reason, and management of postoperative pain during and/or after endodontics treatment.

\section{Pain}

Pain is conceptualized as a psychobiological phenomenon with two components. Pain perception and reaction affected by anesthesia. These emotional states vary from patient to patient, and sometimes disturbances exaggerate the perception of pain [7]. International Association for the Study of Pain defined pain as "an unpleasant sensory and emotional experience associated with actual or potential tissue damage or described in terms of such damage" [8].

\section{Postoperative pain in endodontics}

Postoperative pain is multifactorial and observed as a result of acute periapical inflammation in response to chemical, mechanical, and/or microbial damage of the periapical area during the endodontic treatment [9]. Several factors such as the operator who performs the management, gender, systemic health condition, pulpal and periapical status, preoperative pain, instruments for using preparation, apical patency, irrigation, and obturation technique may affect postoperative pain [3-6]. According to the literature, many studies investigated the influence of different procedural or patient dependent factors during endodontic treatment on the occurrence and intensity of postoperative pain. It 
is concluded that the presence of preoperative pain is the variable that most influences the prevalence of postoperative pain [10]. Also, in most of the studies evaluating postoperative pain after endodontic treatment, women experience pain more than men $[10,11]$.

Endodontic treatment can be performed using hand instruments, engine-driven nickel-titanium instruments such as in continuous rotary, reciprocating, or combined movement called adaptive motion. Many studies suggested that the instrumentation technique may affect the PP. The crown-down technique with multiple rotary systems reduces PP compared with manual instrumentation and reciprocation systems [3]. Adaptive motion is also associated with less PP than reciprocating movement [12]. However, studies suggested that when evaluating patients experiencing pain after endodontic treatment, there was no difference between adaptive and rotary motion $[12,13]$.

There is a preparation technique called apical patency in which the apical region of the root canal is maintained as free of tissue remnants and debris by insertion of an undersized $\mathrm{K}$ file $1 \mathrm{~mm}$ longer than the working length, without impairing apical constriction [14]. Studies presented that there is no relationship between apical patency and PP [15]. Although foraminal enlargement is recommended to contribute to the healing mechanism of an infected tooth, studies reported that foraminal enlargement causes greater PP [16]. In addition to mechanical preparation, irrigation procedures are essential for the success of root canal treatment. There are various irrigation solutions used for different purposes during management. According to a study by Fedorowicz, et al. [17], irrigation solutions did not influence postoperative pain after root canal treatment [17]. However, a study evaluating the concentrations of sodium hypochlorite on PP suggested that the higher concentration of the solution caused more PP [18]. When the different irrigation activation techniques are evaluated, they have similar effects on PP after the treatment of patients with symptomatic irreversible pulpitis with rotary instruments [19]. It was reported that using $2,5^{\circ} \mathrm{C}$ cold saline as the final irrigation solution reduces postoperative pain [20].

Another factor that is thought to affect postoperative pain and many studies have been conducted on this subject is the number of visits. However, the vast majority of studies concluded that the number of visits had no significant effect on PP after primer endodontic treatment $[1,21]$. Besides, when the PP was evaluated after retreatment cases, single-visit endodontic retreatment presented fewer incidences in comparison with 2-visit retreatment [22].

\section{Measuring postoperative pain}

Pain is a subjective phenomenon, that determining and standardizing objectively can be difficult by forming a group at the studies [23]. Various scales were considered to be adequate and reliable. Lickert type scales like Visual Analogue Scale (VAS) or four-point pain scale are the most frequently used measuring tools to determine the intensity of postoperative dental pain for patients [12,24-26]. For pediatric pain assessment, Wong-Baker Faces Pain Rating Scale (WBS) or Faces Pain Scale (FPS) may be more suitable because of containing schematized options of mood $[27,28]$. Additionally, the Verbal Descriptor Scale (VDS), Numeric Rating Scale (NRS), the Present Pain Intensity Scale (PPI) are also used for measuring pain [29-31].

\section{Management of postoperative endodontic pain}

Non-pharmacologic strategies: Anxiety stimulates the patient's nociceptors, causing genomic changes and this negatively affects the healing mechanism. Therefore, inform the patient correctly may reduce postoperative pain [32]. It was reported that as a result of reducing anxiety by informing the patients about the treatment outcomes, the patients have a more comfortable postoperative period [32,33]. Rosenberg, et al. [34] reported that if the tooth has pain upon bitting before treatment, postoperative pain can be reduced by occlusal reduction [34]. However, there is no agreement for the benefits of occlusal reduction to prevent or reduce $\mathrm{PP}$ in the literature. According to a comprehensive review of occlusal reduction, it was concluded that there was not much effect for the first 24 hours to reduce PP, but the effect was observed in 6-days follow-up [35].

Pharmacologic strategies: After the block injection of the long-acting local anesthetic such as bupivacaine etc., drowsiness was achieved for 8-10 hours and postoperative pain decreased [36]. Furthermore, although this issue is controversial, it has been claimed that pre-procedural steroid injection reduces postoperative pain [37]. Non-narcotic analgesics such as nonsteroidal antiinflammatory drugs (NSAIDs) and acetaminophen have effectively been used for the management of patients with endodontic pain [38]. It was reported that a combination of ibuprofen (NSAIDs) $600 \mathrm{mg}$ and acetaminophen $1000 \mathrm{mg}$ is more effective than placebo and ibuprofen alone $[39,40]$. Besides, preoperative NSAIDs use is also effective on PP [41].

\section{Conclusion}

Patients usually evaluate postoperative pain as a skill criterion of the clinician but for endodontic treatment, postoperative pain is not unexpected. Therefore, patients should always be informed that pain may be experienced after the procedure and clinicians should follow up-recent studies about the factors that may cause pain, and if possible, adapt clinical procedures accordingly.

\section{Acknowledgement}

None.

\section{Conflict of Interest}

The author declares any financial interest, or any conflict of interest exists. 


\section{References}

1. Sathorn C, Parashos P, Messer H (2008) The prevalence of postoperative pain and flare-up in single- and multiple-visit endodontic treatment: a systematic review. Int Endod J 41: 91-99.

2. Levin L, Amit A, Ashkenazi M (2006) Post-operative pain and use of analgesic agents following various dental procedures. Am J Dent 19(4): 245-247.

3. Sun C, Sun J, Tan M, Hu B, Gao X, et al. (2018) Pain after root canal treatment with different instruments: A systematic review and metaanalysis. Oral Dis 24(6): 908-919.

4. Nagendrababu V, Gutmann JL (2017) Factors associated with postobturation pain following single-visit nonsurgical root canal treatment: A systematic review. Quintessence Int 48(3): 193-208.

5. Ng YL, Glennon JP, Setchell DJ, Gulabivala K (2004) Prevalence of and factors affecting post-obturation pain in patients undergoing root canal treatment. Int Endod J 37(6): 381-391.

6. Abdulrab S, Rodrigues JC, Al-Maweri SA, Esam Halboub, Ahmed Yaseen, et al. (2018) Effect of Apical Patency on Postoperative Pain: A Metaanalysis. J Endod 44(10): 1467-1473.

7. Bender IB (2000) Pulpal pain diagnosis--a review. J Endod 26(3): 175179.

8. International Association for the Study of Pain-IASP Terminology, Pain Terms.

9. Genet JM, Hart AA, Wesselink PR, Thoden van Velzen SK (1987) Preoperative and operative factors associated with pain after the first endodontic visit. Int Endod J 20: 53-64.

10. Alí A, Olivieri JG, Duran Sindreu F, Francesc Abella, Miguel Roig, et al (2016) Influence of preoperative pain intensity on postoperative pain after root canal treatment: A prospective clinical study. J Dent 45: 39-42.

11. Garcia Font M, Durán Sindreu F, Morelló S, S Irazusta, F Abella, et al. (2018) Postoperative pain after removal of gutta-percha from root canals in endodontic retreatment using rotary or reciprocating instruments: a prospective clinical study. Clin Oral Investig 22(7): 2623-2631.

12. Gambarini G, Testarelli L, De Luca M, Valerio Milana, Gianluca Plotino, et al. (2013) The influence of three different instrumentation techniques on the incidence of postoperative pain after endodontic treatment. Ann Stomatol (Roma) 4(1): 152-155.

13. Özdemir O, Koçak MM, Koçak S, Sağlam BC (2019) Evaluation of Postoperative Pain After Using Different File Systems: A Randomized Clinical Study. Cumhuriyet Dent J 22:3: 292-298.

14. Krunić J, Mladenović I, Žuža A, Radović I, Stojanović N (2019) Influence of Endodontic Procedure on Postoperative Pain - Evidence from Systematic Reviews. Balk J Dent Med 23(3): 121-125.

15. Yaylali IE, Demirci GK, Kurnaz S, Gul Celik, Buglem Ureyen Kaya, et al. (2018) Does Maintaining Apical Patency during Instrumentation Increase Postoperative Pain or Flare-up Rate after Nonsurgical Root Canal Treatment? A Systematic Review of Randomized Controlled Trials. J Endod 44(8): 1228-1236.

16. Borges Silva EA, Guimarães LS, Küchler EC, Antunes LAA, Antunes LS (2017) Evaluation of effect of foraminal enlargement of necrotic teeth on postoperative symptoms: a systematic review and meta-analysis. J Endod 43: 1969-1977.

17. Fedorowicz Z, Nasser M, Sequeira-Byron P (2012) Irrigants for nonsurgical root canal treatment in mature permanent teeth. Cochrane Database Syst Rev CD008948.

18. Mostafa M E H A A, El-Shrief Y A I, Anous W I O, M W Hassan, F T A Salamah, et al. (2020) Postoperative pain following endodontic irrigation using $1.3 \%$ versus $5.25 \%$ sodium hypochlorite in mandibular molars with necrotic pulps: a randomized double-blind clinical trial. Int Endod J 53(2): 154-166.
19. Decurcio DA, Rossi-Fedele G, Estrela C, Pulikkotil SJ, Nagendrababu V (2019) Machine-assisted agitation reduces postoperative pain during root canal treatment: a systematic review and meta-analysis from randomized clinical trials. J Endod 45: 387-393.

20. Keskin C, Özdemir Ö, Uzun İ, Güler B (2017) Effect of intracanal cryotherapy on pain after single-visit root canal treatment. Aust Endod J 43(2): 83-88.

21. Wong AW, Zhang C, Chu CH (2014) A systematic review of nonsurgical single-visit versus multiple-visit endodontic treatment. Clin Cosmet Investig Dent 6: 45-56.

22. Erdem Hepsenoglu Y, Eyuboglu TF, Özcan M (2018) Postoperative Pain Intensity after Single- versus Two-visit Nonsurgical Endodontic Retreatment: A Randomized Clinical Trial. J Endod 44(9): 1339-1346.

23. Seltzer S, Naidorf IJ (1985) Flare-ups in endodontics: I. Etiological factors. J Endod 11(11): 472-478.

24. Cicek E, Koçak MM, Koçak S, Sağlam BC, Türker SA (2017) Postoperative pain intensity after using different instrumentation techniques: a randomized clinical study. J Appl Oral Sci 25: 20-26.

25. Coelho MS, Vilas-Boas L, Tawil PZ (2019) The effects of photodynamic therapy on postoperative pain in teeth with necrotic pulps. Photodiagnosis Photodyn Ther 27: 396-401.

26. Nath R, Daneshmand A, Sizemore D, Guo J, Enciso R (2018) Efficacy of corticosteroids for postoperative endodontic pain: A systematic review and meta-analysis. J Dent Anesth Pain Med 18(4): 205-221.

27. Lawson SL, Hogg MM, Moore CG, et al. (2019) Pediatric Pain Assessment in the Emergency Department: Patient and Caregiver Agreement Using the Wong-Baker FACES and the Faces Pain Scale-Revised.

28. Berlin H, Vall M, Bergenäs E, Karin Ridell, Susanne Brogårdh Roth, et al. (2019) Effects and cost-effectiveness of postoperative oral analgesics for additional postoperative pain relief in children and adolescents undergoing dental treatment: Health technology assessment including a systematic review. PLoS One 14(12): e0227027.

29. Sirintawat N, Sawang K, Chaiyasamut T, Wongsirichat N (2017) Pain measurement in oral and maxillofacial surgery. J Dent Anesth Pain Med 17(4): 253-263.

30. Hjermstad MJ, Fayers PM, Haugen DF, Augusto Caraceni, Geoffrey W Hanks, et al. (2011) Studies comparing Numerical Rating Scales, Verbal Rating Scales, and Visual Analogue Scales for assessment of pain intensity in adults: a systematic literature review. J Pain Symptom Manage 41(6): 1073-1093.

31. Melzack R (2005) The McGill pain questionnaire: from description to measurement. Anesthesiology 103(1): 199-202.

32. Gatchel RJ (1992) Managing anxiety and pain during dental treatment. J Am Dent Assoc 123(6): 37-41.

33. Shavit Y, Lewis JW, Terman GW, Gale RP, Liebeskind JC (1984) Opioid peptides mediate the suppressive effect of stress on natural killer cell cytotoxicity. Science 223(4632): 188-90.

34. Rosenberg PA, Babick PJ, Schertzer L, Leung A (1998) The effect of occlusal reduction on pain after endodontic instrumentation. J Endod 24: 492-496.

35. Nguyen D, Nagendrababu V, Pulikkotil SJ, Rossi Fedele G (2020) Effect of occlusal reduction on postendodontic pain: A systematic review and meta-analysis of randomised clinical trials. Aust Endod J 46(2): 282-294.

36. Keiser K, Hargreaves KM (2002) Building effective strategies for the management of endodontic pain. Endodontic Topics 3(1): 93-105.

37. Jalalzadeh SM, Mamavi A, Shahriari S, Santos FA, Pochapski MT (2010) Effect of pretreatment prednisolone on postendodontic pain: a doubleblind parallelrandomized clinical trial. J Endod 36(6): 978-981.

38. Jayakodi H, Kailasam S, Kumaravadivel K, Thangavelu B, Mathew S (2012) Clinical and pharmacological management of endodontic flareup. J Pharm Bioall Sci 4(2): 294-298. 
39. Smith EA, Marshall JG, Selph SS, Barker DR, Sedgley CM (2017) Nonsteroidal Anti-inflammatory Drugs for Managing Postoperative Endodontic Pain in Patients Who Present with Preoperative Pain: A Systematic Review and Meta-analysis. J Endod 43(1): 7-15.

40. Menhinick KA, Gutmann JL, Regan JD, Taylor SE, Buschang PH (2004) The efficacy of pain control following nonsurgical root canal treatment using ibuprofen or a combination of ibuprofen and acetaminophen in a randomized, double-blind, placebo-controlled study. Int Endod J 37(8): 531-541.

41. Nabi S, Amin K, Masoodi A, Riyaz Farooq, Aamir Rashid Purra, et al. (2018) Effect of preoperative ibuprofen in controlling postendodontic pain with and without low-level laser therapy in single visit endodontics: A randomized clinical study. Indian J Dent Res 29: 46-50. 